Acta Sci. Pol. Technol. Aliment. 15(4) 2016, 379-389

pISSN 1644-0730

eISSN 1889-9594

DOI: 10.17306/J.AFS.2016.4.36

ORIGINAL PAPER

Received: 27.04.2016

Accepted: 14.09.2016

\title{
THE CHANGES OF PROTEINS FRACTIONS SHARES IN MILK AND FERMENTED MILK DRINKS
}

\author{
Genowefa Bonczar ${ }^{凶}$, Maria Walczycka, Iwona Duda
}

Animal Products Technology Department, University of Agriculture in Krakow Balicka 122, 30-149 Kraków, Poland

\begin{abstract}
Background. The aim of this research was to observe the changes which take place in the electrophoretic picture of milk proteins after pasteurisation and inoculation with different starter cultures (both traditional and probiotic). After incubation, the yoghurt, kefir, acidified milk, fermented Bifidobacterium bifidum drink and Lactobacillus acidophillus drink were chilled for 14 days to observe the changes which occurred.

Materials and methods. The research materials were raw and pasteurised milk, as well as fermented milkbased drinks. The raw milk used for research came from Polish Holstein-Fresian black and white cows. The milk was sampled 3 times and divided into 5 parts, each of which was pasteurised at $95^{\circ} \mathrm{C}$ for 10 min and then cooled for inoculation: yoghurt to $45^{\circ} \mathrm{C}$, kefir and acidified milk to $22^{\circ} \mathrm{C}$ and drinks with Bifidobacterium bifidum and Lactobacillus acidophillus to $38^{\circ} \mathrm{C}$. Milk was inoculated with lyophilised, direct vat starter cultures, in an amount equal to $2 \%$ of the working starter. For the production of fermented drinks, the subsequent starters were applied: "YC-180" Christian Hansen for yoghurt, "D” Biolacta-Texel-Rhodia for kefir, CH-N-11 Christian Hansen for acidified milk, starter by Christian Hansen for the probiotic Bifidobacterium bifidum milk, starter by Biolacta-Texel-Rhodia for the probiotic Lactobacillus acidophillus milk. The analyses were conducted in raw, pasteurised and freshly fermented milk as well as in milk drinks stored for 14 days. The total solid content was estimated by the drying method; the fat content by the Gerber method; the lactose content by the Bertrand method; the protein content by the Kjeldahl method with Buchi apparatus; the density of milk was measured with lactodensimeter; acidity with a $\mathrm{pH}$-meter; and potential acidity by Soxhlet-Henkl method (AOAC, 1990). The electrophoretic separation of proteins in raw and pasteurised milk, as well as in freshly produced milk drinks and those stored for 14 days, was performed with SDS-PAGE (on polyacrylamid gel) basing on procedure described by Laemmli (1970).

Results. It was shown that, in comparison with raw milk, the pasteurised milk had smaller amounts of $\alpha s-$, $\beta$ - and $\kappa$-casein, whereas the shares of $\gamma$-casein and peptides were greater, and there were no changes in immunoglobulin, $\alpha$-lactalbumin or $\beta$-lactoglobulin levels, which indicated that hydrolysis of caseins had occurred. In all freshly fermented milk drinks, a drop in $\alpha s$ - and $\beta$-casein was observed relative to raw milk. An increase in peptides and $\gamma$-casein was also noticed (with the exception of acidified milk). There were differences in $\alpha$-lactalbumin and $\beta$-lactoglobulin levels between the different drinks: raw, pasteurised or freshly fermented milk. It was shown that kefir, compared to the other drinks, had the lowest levels of $\alpha s$ - and $\beta$-casein, $\alpha$-lactalbumin and of peptides, as well as the highest level of $\gamma$-casein, which is evidence of an increased rate of hydrolysis in that drink. It was stated that, during the storage of fermented milk drinks, the levels of lactoferrin, serum albumin and peptides significantly increased whereas the content of $\kappa$-casein diminished. The proportions of serum albumin and lactoferrin in fermented milk drinks increased relative to raw milk and/or after storage, which is evidence of aggregation of proteins of low molecular mass into bigger conglomerates. Conclusion. The observed differences between fermented milks, including during chilled storage, in the amounts of individual proteins proves the different proteolytic abilities of starter cultures used in fermented milk production. $\alpha$-lactoalbumin and $\beta$-lactoglobulin are, besides caseins, the most allergenic milk proteins.
\end{abstract}

\footnotetext{
\g.bonczar@ur.krakow.pl
} 
So, kefir, because of its low $\alpha$-lactoalbumin content, and Bifidobacterium bifidum milk, with the lowest content of $\beta$-lactoglobulin, were the most advantageous and least allergenic drinks examined.

Key words: raw milk, pasteurised milk, fermented milks, probiotic fermented milks, protein

\section{INTRODUCTION}

Milk proteins are characterised by diversity in their construction, structure, dimensions (molecular weight), amino acid composition, origin and also by their nutritional value, functional properties etc. (Caira et al., 2012; Creamer, 2003; Ng-Kwai-Hang, 2003; Pinto et al., 2012; Szwajkowska et al., 2011). Various techniques used to separate proteins demonstrate that, in dairy products, there were proteins and their components, peptides and other ammonium-containing compounds. It was also possible to estimate their molecular weights - from about 14 thousand $\mathrm{kDa}(\alpha$-lactalbumin) to 1,430 thousand (immunoglobulins). A molecular weight lower than 14 thousand $\mathrm{kDa}$ was demonstrated by some peptides, proteoses, peptones and amino acids (Ng-Kwai-Hang, 2003). Among the many milk proteins synthesised in milk glands, genetic variations were observed, the extent of which is becoming more evident with the development of separation techniques (Barłowska et al., 2012; Creamer, 2003; Ng-Kwai-Hang, 2003).

Milk proteins can undergo many changes, e.g. coagulation (enzymatic, acidic) and denaturation, and can also be subjected to interactions with other proteins and/or milk components (i.e. when high temperatures are applied). They can also enter into hydrolysis with native milk enzymes and/or microbiological proteases, peptidases and others. The transformations of proteins are key to obtaining accurate information about the properties of dairy products such as cheeses and fermented drinks. Proteins can be also used by harmful or pathogenic microorganisms to support their metabolism, which has an adverse effect on the dairy product and sometimes leads to the creation of hydrolysed products which are harmful to humans (Caira et al., 2012; Crudden et al., 2005; Ismail and Nielsen, 2010; Ng-Kwai-Hang, 2003; Szwajkowska et al., 2011). Milk proteins subjected to hydrolysis can be also a source of biologically active peptides with different and pro-health properties (Meisel, 1997; Meisel, 1998; Szwajkowska et al., 2011). It was proven that protein hydrolysis accompanied by lactic acid milk fermentation evoked by starter cultures can reduce the allergenic properties of milk (Liu et al., 2012; Pinto et al., 2012; Sfaxi et al., 2012; Tzvetkova et al., 2007; Szwajkowska et al., 2011; Wróblewska and Kaliszewska, 2011). Caira et al. (2012), presenting the list of allergenic factors in milk, mentioned all proteins the exception of immunoglobulins, serum albumin and lactoferrin. At the same time Wróblewska and Kaliszewska (2011) described all milk proteins as allergens.

The initial stages of milk protein hydrolysis are initiated by proteases. The most widely known milk proteases are: alcalic (plasmin) and acidic. Microorganism proteases can cause hydrolytic changes as well. During the production of fermented milk drinks, hydrolysis is performed by enzymes of lactic acidfermenting bacteria. The microbiological composition of starter cultures can determine the range, as well as the development of, protein hydrolysis, and the composition of peptides and other products that form after hydrolysis, because the proteolytic activity of the starter microflora is different (Alhaj et al., 2007; Bertrand-Harb et al., 2003; Liu et al., 2012; Pescuma et al., 2008; Pescuma et al., 2012; Reguła and Bonczar, 2005; Sfaxi et al., 2012; Tzvetkova et al., 2007; Yadav et al., 2007).

The aim of the research was to observe the changes taking place in the electrophoretic picture of milk proteins after pasteurisation and inoculation with different starter cultures (both traditional and probiotic). After incubation, the yoghurt, kefir, acidified milk, fermented Bifidobacterium bifidum drink and Lactobacillus acidophillus drink were chilled for 14 days to observe the changes which occurred. 


\section{MATERIALS AND METHODS}

\section{Materials}

The research materials were raw and pasteurised milk, as well as fermented milk products. The raw milk used for research came from Polish Holstein-Fresian black and white cows. It was sampled three times, at one-week intervals, at a barn situated near Krakow (Małopolska, Poland). Each batch contained about 101 of milk. Then the milk was divided into 5 parts, each of which was pasteurised at $95^{\circ} \mathrm{C}$ for $10 \mathrm{~min}$ and then cooled for inoculation: for yoghurt to $45^{\circ} \mathrm{C}$, for kefir and acidified milk to $22^{\circ} \mathrm{C}$, and for drinks with Bifidobacterium bifidum and Lactobacillus acidophillus to $38^{\circ} \mathrm{C}$. Milk was inoculated with lyophilised direct vat starter cultures, in an amount equal to $2 \%$ of the working starter. For the production of fermented drinks, the subsequent starters were applied:

- "YC-180" containing Streptococcus thermophilus and Lactobacillus delbrueckii ssp. bulgaricus by Christian Hansen for yoghurt

- "D" containing Lactobacillus sp., Lactococcus sp., Candida kefir, Kluyveromyces fragilis by Biolacta-Texel-Rhodia for kefir

- CH-N-11 containing Lactococcus lactis ssp. cremoris, Lactococcus lactis ssp. lactis, Lactococcus lactis ssp. diacetilactis, Leuconostoc mesenteroides, ssp. cremoris by Christian Hansen for acidified milk

- starter by Christian Hansen for the probiotic Bifidobacterium bifidum drink

- starter by Biolacta-Texel-Rhodia for the probiotic Lactobacillus acidophillus drink.

Yoghurt incubation was performed at $45^{\circ} \mathrm{C}$ for $6 \mathrm{~h}$ (hours); kefir and acidified milk at $22^{\circ} \mathrm{C}$ for $16 \mathrm{~h}$; probiotic drink at $38^{\circ} \mathrm{C}$ for $12 \mathrm{~h}$. After obtaining $\mathrm{pH} 4.7$, the drinks were cooled and stored for 14 days at $4^{\circ} \mathrm{C}$.

The analyses were conducted in raw, pasteurised and freshly fermented milk, as well as in milk drinks stored for 14 days.

\section{Analytical methods}

The total solid content was estimated by the drying method; the fat content by the Gerber method; the lactose content by the Bertrand method; the protein content by the Kjeldahl method with Buchi apparatus; the density of milk was measured with lactodensimeter; active acidity with a $\mathrm{pH}$-meter; and potential acidity by Soxhlet-Henkl method (AOAC, 1990).

The electrophoretic separation of proteins in raw and pasteurised milk, as well as in freshly produced milk drinks and those stored for 14 days, was performed with SDS-PAGE on polyacrylamid gel according to method described by Laemmli (1970). The separation was conducted with the use of the Mini Protein 3 Cell apparatus (by Biorad). The gels were dyed with R250 Coomassie blue, and the electrophoretic stripes of separated protein fractions were scanned and analysed with electrophoresis gel analysing software Gelscan v. 2.0 (by Kucharczyk), which allowed the quantitative estimation of separated protein fractions. The standards for qualitative comparison and identification of the protein fractions were provided by Sigma-Aldrich.

\section{Statistical analysis}

The statistical analysis of the results was performed by calculating the arithmetic means and the standard errors for raw milk. The results concerning the electrophoretic separation of proteins in raw, pasteurised milks and freshly fermented drinks were elaborated through calculation of ANOVA. In order to estimate the influence that storage time and method of drink preparation have on the electrophoretic decomposition of proteins, the 2-factor MANOVA was performed. The statistical significance of differences between means was estimated with post-hoc Duncan test. The licensed version 9 of Statistica (StatSoft Inc.) software was used for all calculations.

\section{RESULTS AND DISCUSSION}

The raw cow's milk used for the production of fermented milk drinks, after pasteurisation, contained on average: $12.41 \% \pm 0.85$ of total solids, $3.21 \% \pm 0.18$ of protein, $3.85 \% \pm 0.54$ of fat and $4.70 \% \pm 0.32$ of lactose. The $\mathrm{pH}$ of the milk was $6.65 \pm 0.05$, the titratable acidity was $6.80 * \mathrm{SH} \pm 0.75$ and the density was 1.0295 $\mathrm{g} / \mathrm{cm}^{3} \pm 0.0001$. The levels of the above-mentioned parameters were in accordance with other authors' findings (Barłowska et al., 2011).

The proportion of individual protein fractions $[\mathrm{g} / \mathrm{l}]$ in raw, pasteurised and freshly fermented milks are presented in Table 1. 
Ng-Kwai-Hang (2003) reported that cow's milk contained about $12.6 \mathrm{~g} / 1$ of $\alpha s$-casein, $9.3 \mathrm{~g} / \mathrm{l}$ of $\beta$-casein, $3.3 \mathrm{~g} / 1$ of $\kappa$-casein, $3.2 \mathrm{~g} / \mathrm{l}$ of $\beta$-lactoglobulin, $1.2 \mathrm{~g} / 1$ of $\alpha$-lactalbumin, $0.4 \mathrm{~g} / 1$ of serum albumin and $0.8 \mathrm{~g} / \mathrm{l}$ of immunoglobulins. In comparison to the data presented above, this experimental raw milk contained less $\beta$-casein and $\alpha$-casein and more $\kappa$-casein and whey proteins. In raw milk, some peptides were also present (Table 1). The differences in protein composition between our data and data from our cited sources could be influenced by genetic factors and the feeding system (Barłowska et al., 2012; Brodziak at al., 2015; Król et al., 2011; Kuczyńska et al., 2012a; Kuczyńska et al., 2012b), and/or by partial hydrolysis of proteins, which was supported by the presence of peptides in the examined milk. This hydrolysis could be the result of native milk enzyme activity (plasmin) and/or proteases originating from incidental milk microflora (Crudden et al., 2005; Ismail and Nielsen, 2010; Yasser et al., 2010). During electrophoresis, as a result of hydrolysis, some peptides with a molecular mass similar to alpha-albumin could be produced, which, when the proteins were separated, was found in the same band.

In pasteurised milk, the share of $\alpha s_{-}, \beta-, \kappa$-caseins was slightly diminished (statistically significant for $\kappa$-casein), and the emergence of $\gamma$-casein was observed. As we have already discussed, the $\gamma$-caseins are parts of $\beta$-casein and are formed during milk hydrolysis by plasmin. It was observed that plasmin hydrolytic activity diminishes after pasteurisation, sometimes by more than dozens of percent, but the activator of plasminogen inhibitor denatures, which allows for the activation of plasminogen which in turn transforms into plasmin and the hydrolysis of casein continues. Plasmin most often shows the tendency to hydrolyse $\beta$-casein, but it was also observed that it acted against other caseins, with little or no activity against $\alpha$-lactalbumin and $\beta$-lactoglobulin (Crudden et al., 2005; Ismail and Nielsen, 2010; Yasser et al., 2010). According to Lorenzen et al. (2011) the content of proteins in pasteurised milk was not different from that in raw milk, and only the ratios of individual proteins is changed as a result of denaturation and interactions between proteins. The small increase in serum albumin and/or lactoferrin content in pasteurised milk observed in this experiment could be caused by smaller proteins combining into larger aggregates.
The statistically significant increase in peptides which was observed in pasteurised milk was probably linked to the hydrolysis of casein proteins, because the levels of whey proteins was not changed. This confirms the statement that plasmin does not hydrolyse whey proteins (Ismail and Nielsen, 2010; Yasser et al., 2010).

The contents of immunoglobulins and $\alpha s-$ and $\beta$-caseins decreased significantly, whereas the contents of serum albumins and peptides increased in all freshly prepared fermented milks in comparison to pasteurised milk (Table 1). The biggest decrease in $\alpha s-$ and $\beta$-caseins and $\alpha$-lactalbumin levels was observed in kefir, where an increase of $\gamma$-casein was also noticed. The contents of lactoferrin and $\beta$-lactoglobulin in milk and fermented milks did not change statistically (Table 1).

The influence of starter cultures on the level and character of proteolysis was investigated by other authors, who observed the variety of proteolytic abilities depending on microbiological starter culture composition (Alhaj et al., 2007; Bertrand-Harb et al., 2003; Sfaxi et al., 2012). In some papers, milk rods were found to have stronger proteolytic abilities than milk cocci (Bertrand-Harb et al., 2003; Sfaxi et al., 2012). It was also mentioned that Lactobacillus milk rods had weaker hydrolytic abilities against $\alpha s$-casein than against $\beta$-casein (Sfaxi et al., 2012). The results obtained in this experiment revealed that Lactobacillus acidophilus hydrolysed $26 \%$ of $\beta$-casein and $14 \%$ of $\alpha s$-casein present in milk, which was in accordance with accepted data.

The observed growth of peptide levels in assessed fermented milks was linked to the hydrolysis of proteins with higher molecular weight. It was shown that the hydroysis of caseins to low molecular weightpeptides decreased the allergenic properties of milk caused by the presence of $\alpha$-, $\beta$ - and $\kappa$-caseins (Caira et al., 2012; Liu et al., 2012; Ng-Kwai-Hang, 2003; Pinto et al., 2012; Sfaxi et al., 2012; Szwajkowska et al., 2011; Tzvetkova et al., 2007). According to Wróblewska and Kaliszewska (2011) milk fermentation lowers the immunoactivity of kefir, yoghurt and butter, whereas Szwajkowska et al. (2011) stated that peptides containing 3-20 amino acids have a positive influence on the physiological functions of the human body. 
Bonczar, G., Walczycka, M., Duda, I. (2016). The changes of proteins fractions shares in milk and fermented milk drinks. Acta Sci. Pol. Technol. Aliment., 15(4), 379-389. DOI: 10.17306/J.AFS.2016.4.36

Table 1. Changes of protein fractions in milk and fermented milks (the least squared means and means standard errors)

\begin{tabular}{|c|c|c|c|c|c|c|c|c|}
\hline \multirow{3}{*}{$\begin{array}{l}\text { Protein fractions } \\
\qquad \mathrm{g} / \mathrm{dm}^{3}\end{array}$} & \multirow{3}{*}{$\begin{array}{l}\text { Mo- } \\
\text { lecular } \\
\text { mass } \\
\mathrm{kDa}\end{array}$} & \multicolumn{7}{|c|}{ Kind of fermented milk } \\
\hline & & raw milk & $\begin{array}{l}\text { pasteurised } \\
\text { milk }\end{array}$ & yoghurt & kefir & $\begin{array}{l}\text { acidified } \\
\text { milk }\end{array}$ & $\begin{array}{c}\text { Bifidobacte- } \\
\text { rium } \\
\text { milk }\end{array}$ & $\begin{array}{c}\text { Lacto- } \\
\text { bacillus } \\
\text { acidophillus } \\
\text { milk }\end{array}$ \\
\hline & & $\overline{\mathrm{x}} \pm \mathrm{S}$ & $\overline{\mathrm{x}} \pm \mathrm{s}$ & $\overline{\mathrm{x}} \pm \mathrm{s}$ & $\overline{\mathrm{x}} \pm \mathrm{S}$ & $\overline{\mathrm{x}} \pm \mathrm{S}$ & $\overline{\mathrm{x}} \pm \mathrm{s}$ & $\overline{\mathrm{x}} \pm \mathrm{S}$ \\
\hline Immunoglobulins & 150 & $\begin{array}{c}0.93^{\mathrm{A}} \\
\pm 0.03\end{array}$ & $\begin{aligned} & 0.93^{\mathrm{A}} \\
\pm & 0.03\end{aligned}$ & $\begin{aligned} & 0.32^{\mathrm{B}} \\
\pm & 0.01\end{aligned}$ & $\begin{aligned} & 0.36^{\mathrm{B}} \\
\pm & 0.05\end{aligned}$ & $\begin{array}{l} \\
0.44^{\mathrm{B}} \\
\pm 0.10\end{array}$ & $\begin{aligned} & 0.30^{\mathrm{B}} \\
\pm & 0.09\end{aligned}$ & $\begin{array}{l} \\
0.39^{\mathrm{B}} \\
\pm 0.02\end{array}$ \\
\hline Lactoferrin & 80 & $\begin{array}{r}0.40 \\
\pm 0.03\end{array}$ & $\begin{array}{r}0.44 \\
\pm 0.02\end{array}$ & $\begin{array}{r}0.49 \\
\pm 0.10\end{array}$ & $\begin{array}{r}0.54 \\
\pm 0.09\end{array}$ & $\begin{array}{r}0.48 \\
\pm 0.01\end{array}$ & $\begin{array}{r}0.38 \\
\pm 0.05\end{array}$ & $\begin{array}{r}0.42 \\
\pm 0.02\end{array}$ \\
\hline Serum albumin & 66 & $\begin{aligned} & 0.47^{\mathrm{A}} \\
\pm & 0.03\end{aligned}$ & $\begin{aligned} & 0.50^{\mathrm{Aa}} \\
\pm & 0.01\end{aligned}$ & $\begin{aligned} & 0.64^{\mathrm{A}} \\
\pm & 0.01\end{aligned}$ & $\begin{array}{l}0.86^{\mathrm{B}} \\
\pm 0.08\end{array}$ & $\begin{aligned} & 1.01^{\mathrm{B}} \\
\pm & 0.04\end{aligned}$ & $\begin{aligned} & 0.70^{\text {Aba }} \\
\pm & 0.14\end{aligned}$ & $\begin{aligned} & 0.78^{\mathrm{Bb}} \\
\pm & 0.04\end{aligned}$ \\
\hline$\alpha$-casein & 26 & $\begin{array}{l}12.08^{\mathrm{Aa}} \\
\pm 0.18\end{array}$ & $\begin{array}{l}11.09^{\mathrm{a}} \\
\pm 0.67\end{array}$ & $\begin{array}{r}9.68^{\mathrm{B}} \\
\pm 0.06\end{array}$ & $\begin{aligned} & 9.37^{\mathrm{Bb}} \\
\pm & 0.47\end{aligned}$ & $\begin{array}{l}10.28^{\mathrm{b}} \\
\pm 0.24\end{array}$ & $\begin{array}{l}10.50^{\mathrm{b}} \\
\pm 0.79\end{array}$ & $\begin{aligned} & 9.63^{\mathrm{B}} \\
\pm & 0.43\end{aligned}$ \\
\hline$\beta$-casein & 24 & $\begin{array}{l}\quad 6.87^{\text {Aa }} \\
\pm 0.30\end{array}$ & $\begin{aligned} & 6.69^{\text {Aa }} \\
\pm & 0.24\end{aligned}$ & $\begin{aligned} & 6.16^{\mathrm{a}} \\
\pm & 0.33\end{aligned}$ & $\begin{aligned} & 4.99^{\mathrm{Bb}} \\
\pm & 0.15\end{aligned}$ & $\begin{aligned} & 5.19^{\mathrm{Bb}} \\
\pm & 0.35\end{aligned}$ & $\begin{aligned} & 5.42^{\mathrm{b}} \\
\pm & 0.22\end{aligned}$ & $\begin{aligned} & 4.93^{\mathrm{b}} \\
\pm & 0.59\end{aligned}$ \\
\hline$\kappa$-casein & 19 & $\begin{array}{r}4.69^{\mathrm{a}} \\
\pm 0.16\end{array}$ & $\begin{aligned} & 4.50^{\mathrm{Aabc}} \\
\pm & 0.09\end{aligned}$ & $\begin{aligned} & 4.27^{\mathrm{Ab}} \\
\pm & 0.15\end{aligned}$ & $\begin{array}{c}5.04^{\mathrm{B}} \\
\pm 0.10\end{array}$ & $\begin{aligned} & 4.79^{\mathrm{a}} \\
\pm & 0.08\end{aligned}$ & $\begin{aligned} & 5.08^{\mathrm{B}} \\
\pm & 0.09\end{aligned}$ & $\begin{aligned} & 4.99^{\mathrm{b}} \\
\pm & 0.13\end{aligned}$ \\
\hline$\beta$-lactoglobulin & 18 & $\begin{array}{r}3.71 \\
\pm 0.29\end{array}$ & $\begin{array}{r}3.71 \\
\pm 0.29\end{array}$ & $\begin{array}{r}3.69 \\
\pm 0.31\end{array}$ & $\begin{array}{r}3.38 \\
\pm 0.20\end{array}$ & $\begin{array}{r}3.70 \\
\pm 0.09\end{array}$ & $\begin{array}{r}3.18 \\
\pm 0.07\end{array}$ & $\begin{array}{r}3.75 \\
\pm 0.18\end{array}$ \\
\hline$\alpha$-lactalbumin & 14 & $\begin{array}{r}2.45 \\
\pm 0.24\end{array}$ & $\begin{array}{r}2.45 \\
\pm 0.25\end{array}$ & $\begin{array}{r}2.48 \\
\pm 0.25\end{array}$ & $\begin{array}{r}1.89^{\mathrm{a}} \\
\pm 0.21\end{array}$ & $\begin{array}{r}2.78^{\mathrm{b}} \\
\pm 0.28\end{array}$ & $\begin{array}{r}2.58 \\
\pm 0.10\end{array}$ & $\begin{aligned} & 2.66^{\mathrm{bc}} \\
\pm & 0.09\end{aligned}$ \\
\hline $\begin{array}{l}\text { Low molecular } \\
\text { mass peptides }\end{array}$ & $<12$ & $\begin{array}{c}0.54^{\mathrm{Aa}} \\
\pm 0.09\end{array}$ & $\begin{aligned} & 0.81^{\mathrm{A}} \\
\pm & 0.03\end{aligned}$ & $\begin{aligned} & 1.59^{\mathrm{A}} \\
\pm & 0.49\end{aligned}$ & $\begin{aligned} & 1.39^{\mathrm{A}} \\
\pm & 0.10\end{aligned}$ & $\begin{aligned} & 3.39^{\mathrm{Ba}} \\
\pm & 0.36\end{aligned}$ & $\begin{aligned} & 1.43^{\mathrm{A}} \\
\pm & 0.77\end{aligned}$ & $\begin{aligned} & 2.18^{\mathrm{b}} \\
\pm & 0.14\end{aligned}$ \\
\hline$\gamma$-casein & 6 & $\begin{array}{l}0.00^{\mathrm{Aa}} \\
\pm 0.00\end{array}$ & $\begin{array}{l}1.01^{\mathrm{Bb}} \\
\pm 0.08\end{array}$ & $\begin{aligned} & 1.87^{\mathrm{B}} \\
\pm & 0.28\end{aligned}$ & $\begin{aligned} & 4.32^{\mathrm{BCD}} \\
\pm & 0.73\end{aligned}$ & $\begin{array}{l}0.00^{\mathrm{Aa}} \\
\pm 0.00\end{array}$ & $\begin{array}{l}2.56^{\mathrm{BC}} \\
\pm 0.06\end{array}$ & $\begin{array}{l}2.36^{\mathrm{BC}} \\
\pm 0.14\end{array}$ \\
\hline
\end{tabular}

A,B Statistically significant differences, at $p \leq 0.01$, between means in rows.

${ }^{\mathrm{a}, \mathrm{b}}$ Statistically significant differences, at $p \leq 0.05$, between means in rows.

The changes to the protein composition of the experimental fermented milks during chilled storage are presented in Table 2 and Figures from 1 to 5.

It was observed that, for the fermented milks, 14 days of refrigerated storage caused a statistically significant increase in lactoferrin and albumin (or of proteins with similar molecular weight; $80 \mathrm{kDa}$ and $66 \mathrm{kDa}$ respectively) and an increase in peptides with a molecular weight of less than $12 \mathrm{kDa}$, and was also responsible for the parallel drop-off of $\kappa$-casein levels. The changes in levels of other proteins after 14 days of storage were not statistically significant.
The differences in protein composition between day 1 and day 14 of storage of the fermented milks proved that, in the assessed fermented milks, not only hydrolysis but also aggregation of small molecular weight compounds had taken place, which was confirmed by results obtained by Zúñiga et al. (2010). It was observed that when $\beta$-lactalbumin was subjected to different hydrogenic ion concentrations $(\mathrm{pH})$ and to thermal treatment, the conditions were obtained for large spherical aggregates at $\mathrm{pH} 6.0$ and for small and linear aggregates at $\mathrm{pH} 6.8$.

The results of ANOVA (Table 2) and data plotted on Figures 1-5 pointed to differences in the content of 
Bonczar, G., Walczycka, M., Duda, I. (2016). The changes of proteins fractions shares in milk and fermented milk drinks. Acta Sci. Pol. Technol. Aliment., 15(4), 379-389. DOI: 10.17306/J.AFS.2016.4.36

Table 2. Changes of protein fractions in fermented milk drinks during storage (the least squared means and means standard errors)

\begin{tabular}{|c|c|c|c|c|c|c|c|c|}
\hline \multirow{3}{*}{$\begin{array}{l}\text { Protein fractions } \\
\qquad \mathrm{g} / \mathrm{dm}^{3}\end{array}$} & \multirow{3}{*}{$\begin{array}{l}\text { Mo- } \\
\text { lecular } \\
\text { mass } \\
\mathrm{kDa}\end{array}$} & \multicolumn{2}{|c|}{ Days of storage } & \multicolumn{5}{|c|}{ Kind of fermented milk } \\
\hline & & 1 & 14 & yoghurt & kefir & $\begin{array}{l}\text { acidified } \\
\text { milk }\end{array}$ & $\begin{array}{c}\text { Bifidobacte- } \\
\text { rium } \\
\text { milk }\end{array}$ & $\begin{array}{c}\text { Lacto- } \\
\text { bacillus } \\
\text { acidophillus } \\
\text { milk }\end{array}$ \\
\hline & & $\overline{\mathrm{x}} \pm \mathrm{S}$ & $\overline{\mathrm{x}} \pm \mathrm{s}$ & $\overline{\mathrm{x}} \pm \mathrm{S}$ & $\overline{\mathrm{x}} \pm \mathrm{S}$ & $\overline{\mathrm{x}} \pm \mathrm{S}$ & $\overline{\mathrm{x}} \pm \mathrm{S}$ & $\overline{\mathrm{x}} \pm \mathrm{S}$ \\
\hline Immunoglobulins & 150 & $\begin{array}{r}0.36 \\
\pm 0.03\end{array}$ & $\begin{array}{r}0.43 \\
\pm 0.01\end{array}$ & $\begin{array}{r}0.36 \\
\pm 0.02\end{array}$ & $\begin{array}{r}0.40 \\
\pm 0.03\end{array}$ & $\begin{array}{l}0.46^{\mathrm{a}} \\
\pm 0.05\end{array}$ & $\begin{aligned} & 0.33^{\mathrm{b}} \\
\pm & 0.05\end{aligned}$ & $\begin{array}{r}0.42 \\
\pm 0.02\end{array}$ \\
\hline Lactoferrin & 80 & $\begin{aligned} & 0.46^{\mathrm{A}} \\
\pm & 0.03\end{aligned}$ & $\begin{aligned} & 0.67^{\mathrm{B}} \\
\pm & 0.06\end{aligned}$ & $\begin{array}{r}0.52 \\
\pm 0.06\end{array}$ & $\begin{array}{r}0.64 \\
\pm 0.06\end{array}$ & $\begin{array}{r}0.68^{\mathrm{a}} \\
\pm 0.09\end{array}$ & $\begin{aligned} & 0.45^{\mathrm{b}} \\
\pm & 0.08\end{aligned}$ & $\begin{array}{r}0.53 \\
\pm 0.09\end{array}$ \\
\hline Serum albumin & 66 & $\begin{aligned} & 0.80^{\mathrm{A}} \\
\pm & 0.05\end{aligned}$ & $\begin{aligned} & 1.00^{\mathrm{B}} \\
\pm & 0.06\end{aligned}$ & $\begin{array}{l}0.72^{\mathrm{Aa}} \\
\pm 0.05\end{array}$ & $\begin{aligned} & 0.93^{\mathrm{bA}} \\
\pm & 0.05\end{aligned}$ & $\begin{aligned} & 1.19^{\mathrm{B}} \\
& \pm 0.09\end{aligned}$ & $\begin{array}{l}0.81^{\mathrm{A}} \\
\pm 0.10\end{array}$ & $\begin{aligned} & 0.85^{\mathrm{A}} \\
\pm & 0.04\end{aligned}$ \\
\hline$\alpha$-casein & 26 & $\begin{array}{r}9.89 \\
\pm 0.24\end{array}$ & $\begin{array}{r}9.25 \\
\pm 0.22\end{array}$ & $\begin{array}{r}9.32 \\
\pm 0.42\end{array}$ & $\begin{array}{r}9.14 \\
\pm 0.32\end{array}$ & $\begin{array}{r}9.96 \\
\pm 0.21\end{array}$ & $\begin{array}{l}10.03 \\
\pm 0.54\end{array}$ & $\begin{array}{r}9.42 \\
\pm 0.30\end{array}$ \\
\hline$\beta$-casein & 24 & $\begin{array}{r}5.34 \\
\pm 0.18\end{array}$ & $\begin{array}{r}5.09 \\
\pm 0.17\end{array}$ & $\begin{aligned} & 6.02^{\mathrm{Aa}} \\
\pm & 0.21\end{aligned}$ & $\begin{array}{r}4.83^{\mathrm{B}} \\
\pm 0.10\end{array}$ & $\begin{array}{r}5.06^{\mathrm{b}} \\
\pm 0.21\end{array}$ & $\begin{aligned} & 5.27^{\mathrm{b}} \\
\pm & 0.19\end{aligned}$ & $\begin{aligned} & 4.91^{\mathrm{B}} \\
\pm & 0.36\end{aligned}$ \\
\hline$\kappa$-casein & 19 & $\begin{array}{r} \\
4.84^{\mathrm{a}} \\
\pm 0.09\end{array}$ & $\begin{array}{r} \\
\quad 4.65^{\mathrm{b}} \\
\pm 0.10\end{array}$ & $\begin{array}{r}4.18^{\mathrm{A}} \\
\pm 0.10\end{array}$ & $\begin{array}{r}4.86^{\mathrm{B}} \\
\pm 0.10\end{array}$ & $\begin{aligned} & 4.66^{\mathrm{BC}} \\
\pm & 0.07\end{aligned}$ & $\begin{aligned} & 5.10^{\mathrm{BD}} \\
\pm & 0.09\end{aligned}$ & $\begin{aligned} & 4.91^{\mathrm{B}} \\
\pm & 0.08\end{aligned}$ \\
\hline$\beta$-lactoglobulin & 18 & $\begin{array}{r}3.54 \\
\pm 0.09\end{array}$ & $\begin{array}{r}3.38 \\
\pm 0.10\end{array}$ & $\begin{aligned} & 3.69^{\mathrm{a}} \\
\pm & 0.19\end{aligned}$ & $\begin{array}{r}3.30 \\
\pm 0.16\end{array}$ & $\begin{aligned} & 3.64^{\mathrm{a}} \\
& \pm 0.05\end{aligned}$ & $\begin{aligned} & 3.09^{\mathrm{b}} \\
\pm & 0.06\end{aligned}$ & $\begin{array}{r}3.59^{\mathrm{a}} \\
\pm 0.14\end{array}$ \\
\hline$\alpha$-lactalbumin & 14 & $\begin{array}{r}2.48 \\
\pm 0.11\end{array}$ & $\begin{array}{r}2.47 \\
\pm 0.12\end{array}$ & $\begin{array}{r}2.49^{\mathrm{A}} \\
\pm 0.16\end{array}$ & $\begin{aligned} & 1.85^{\text {В }} \\
\pm & 0.14\end{aligned}$ & $\begin{aligned} & 2.78^{\mathrm{A}} \\
\pm & 0.18\end{aligned}$ & $\begin{aligned} & 2.57^{\mathrm{A}} \\
\pm & 0.09\end{aligned}$ & $\begin{aligned} & 2.69^{\mathrm{A}} \\
\pm & 0.06\end{aligned}$ \\
\hline $\begin{array}{l}\text { Low molecular } \\
\text { mass peptides }\end{array}$ & $<12$ & $\begin{array}{r}2.00^{\mathrm{a}} \\
\pm 0.26\end{array}$ & $\begin{array}{r}2.76^{\mathrm{b}} \\
\pm 0.30\end{array}$ & $\begin{aligned} & 1.85^{\mathrm{A}} \\
\pm & 0.31\end{aligned}$ & $\begin{aligned} & 1.46^{\mathrm{Aa}} \\
\pm & 0.14\end{aligned}$ & $\begin{aligned} & 3.56^{\mathrm{B}} \\
\pm & 0.23\end{aligned}$ & $\begin{array}{r}2.75^{\mathrm{b}} \\
\pm 0.74\end{array}$ & $\begin{aligned} & 2.28^{\mathrm{B}} \\
\pm & 0.10\end{aligned}$ \\
\hline$\gamma$-casein & 6 & $\begin{array}{r}2.22 \\
\pm 0.39\end{array}$ & $\begin{array}{r}2.11 \\
\pm 0.45\end{array}$ & $\begin{array}{c}2.02^{\mathrm{A}} \\
\pm 0.19\end{array}$ & $\begin{aligned} & 4.49^{\mathrm{B}} \\
\pm & 0.43\end{aligned}$ & $\begin{array}{c}0.00^{\mathrm{D}} \\
\pm 0.00\end{array}$ & $\begin{aligned} & 1.69^{\mathrm{ABDa}} \\
\pm & 0.43\end{aligned}$ & $\begin{aligned} & 2.63^{\mathrm{ABDb}} \\
\pm & 0.17\end{aligned}$ \\
\hline
\end{tabular}

\footnotetext{
${ }^{\mathrm{A}, \mathrm{B}}$ Statistically significant differences, at $p \leq 0.01$, between means in rows.
}

${ }^{\mathrm{a}, \mathrm{b}}$ Statistically significant differences, at $p \leq 0.05$, between means in rows.

individual proteins, depending on which starter culture was used for the production of the fermented milks.

Yoghurt (Table 2, Fig. 1) contained the largest amounts of $\beta$-casein and $\beta$-lactalbumin and the smallest amount of serum albumin, which could indicate a greater extent of hydrolysis of high molecular weight serum albumin and a lesser extent of hydrolysis of the two other proteins.

Kefir contained the largest quantities of $\gamma$-caseins and the smallest quantities of $\alpha s$ - and $\beta$-caseins, which demonstrated a greater extent of hydrolysis involving caseins, especially $\beta$-casein.
Acidified milk (Table 2, Fig. 3), in comparison to other fermented milks, contained the highest levels of immunoglobulins, lactoferrin, serum albumin, a-lactalbumin and peptides and did not contain $\gamma$-caseins, which could be influenced by the lesser extent of hydrolysis of high molecular weight proteins.

Fermented milk with Bifidobacterium bifidum (Table 2, Fig. 4), in comparison to other fermented milks, contained the highest levels of $\alpha s$-casein and $\kappa$-casein and the lowest of immunoglobulins, lactoferrin and $\beta$-lactoglobulin, which confirmed the high proteolitic ability of the above mentioned starter bacteria against 
Bonczar, G., Walczycka, M., Duda, I. (2016). The changes of proteins fractions shares in milk and fermented milk drinks. Acta Sci. Pol. Technol. Aliment., 15(4), 379-389. DOI: 10.17306/J.AFS.2016.4.36

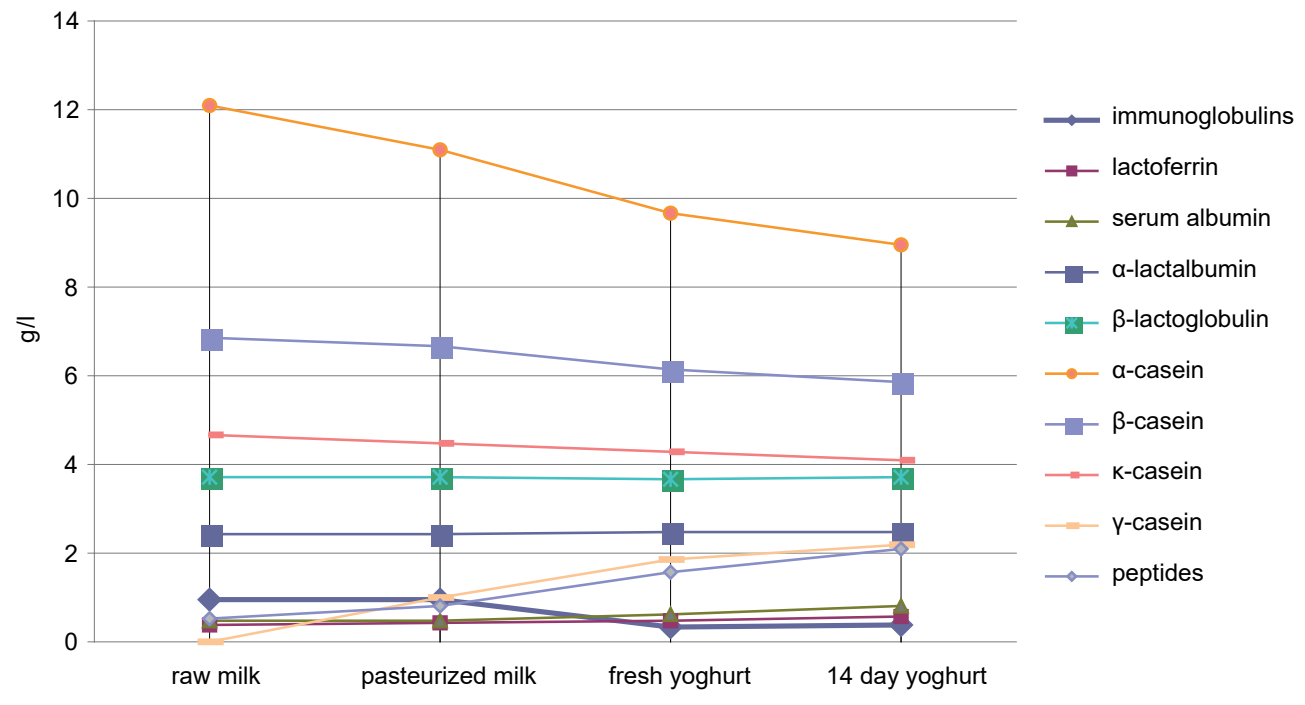

Fig. 1. Changes of protein fractions in milk and yoghurt

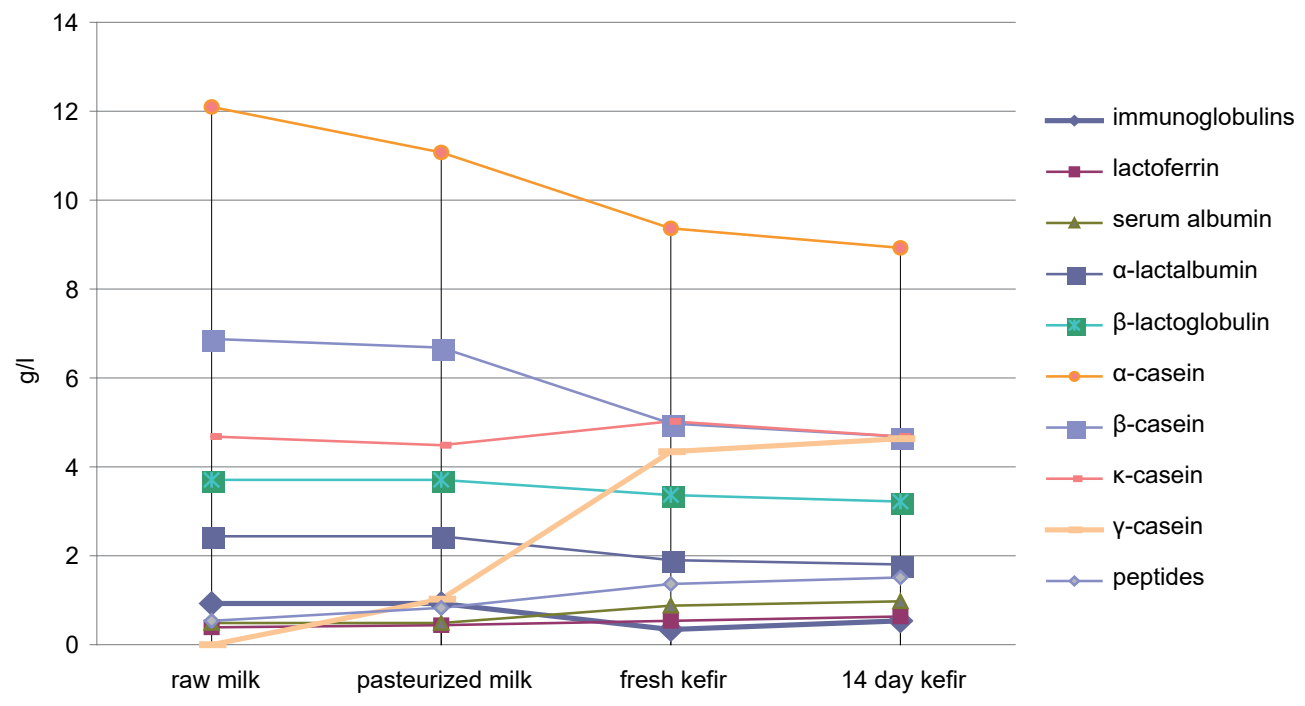

Fig. 2. Changes of protein fractions in milk and kefir

high molecular weight proteins and low ability against caseins.

In fermented milk with Lactobacillus acidophilus, the contents of individual proteins ranged between values observed for other fermented milks in the experiment (Fig. 5).

In Table 3 the percentage changes of protein composition and peptides over 14 days of storage are presented, showing fermented milks in comparison to pasteurised milk.

Among caseins, the $\beta$-casein in fermented milks was hydrolysed to a greater extent than $\alpha$-casein (12.3-30.3\% and $13.0-19.3 \%$ respectively). The largest increase in the proportion of polypeptides (over $400 \%$ ) was observed in the Bifidobacterium milk, and of $\gamma$-casein $(360 \%)$ in kefir. The content of high 
Bonczar, G., Walczycka, M., Duda, I. (2016). The changes of proteins fractions shares in milk and fermented milk drinks. Acta Sci. Pol. Technol. Aliment., 15(4), 379-389. DOI: 10.17306/J.AFS.2016.4.36

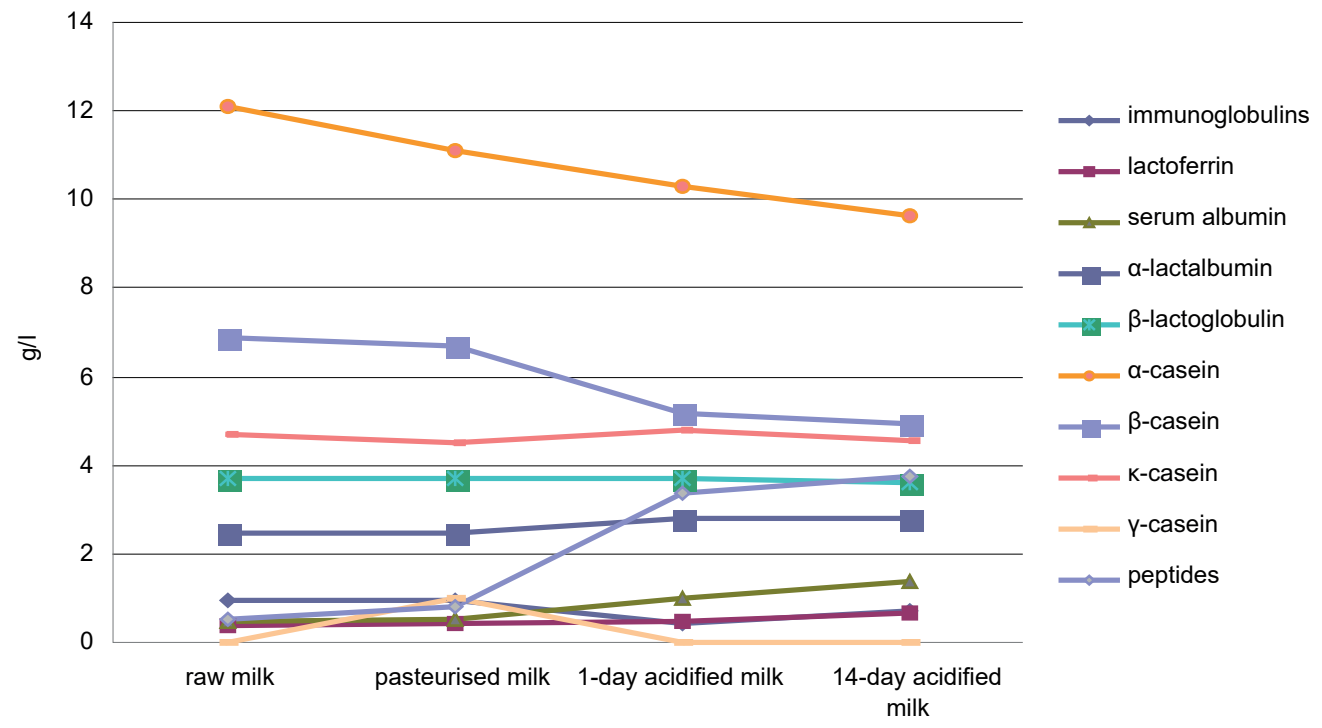

Fig. 3. Changes of protein fractions in milk and acidified milk

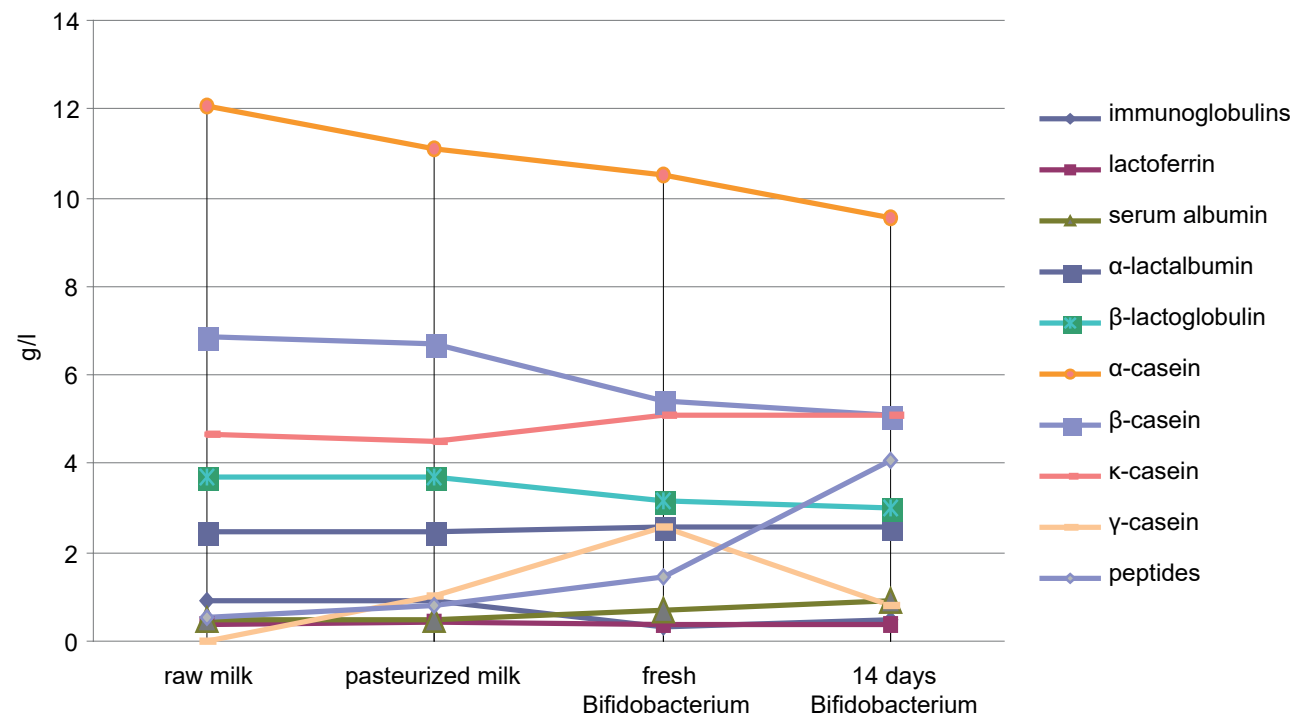

Fig. 4. Changes in protein fractions in milk and fermented with Bifidobacterium bifidum milk

molecular weight proteins - serum albumin and lactoferrin and/or proteins with the similar molecular weight increased in most fermented milks (Table 3).

According to Liu et al. (2012), Pescuma et al. (2012), Bertrand-Harb et al. (2003) Streptococcus thermophillus and Lactobacillus delbrueckii ssp. bulgaricus have the ability to hydrolyse both caseins and whey proteins. In the opinion of Tzvetkova et al. (2007) and of Alhaj et al. (2007), milk caseins undergo hydrolysis more easily in the presence of different types of yoghurt starter culture bacteria than whey proteins. Yadav et al. (2007) stated that, in the traditional 
Bonczar, G., Walczycka, M., Duda, I. (2016). The changes of proteins fractions shares in milk and fermented milk drinks. Acta Sci. Pol. Technol. Aliment., 15(4), 379-389. DOI: 10.17306/J.AFS.2016.4.36

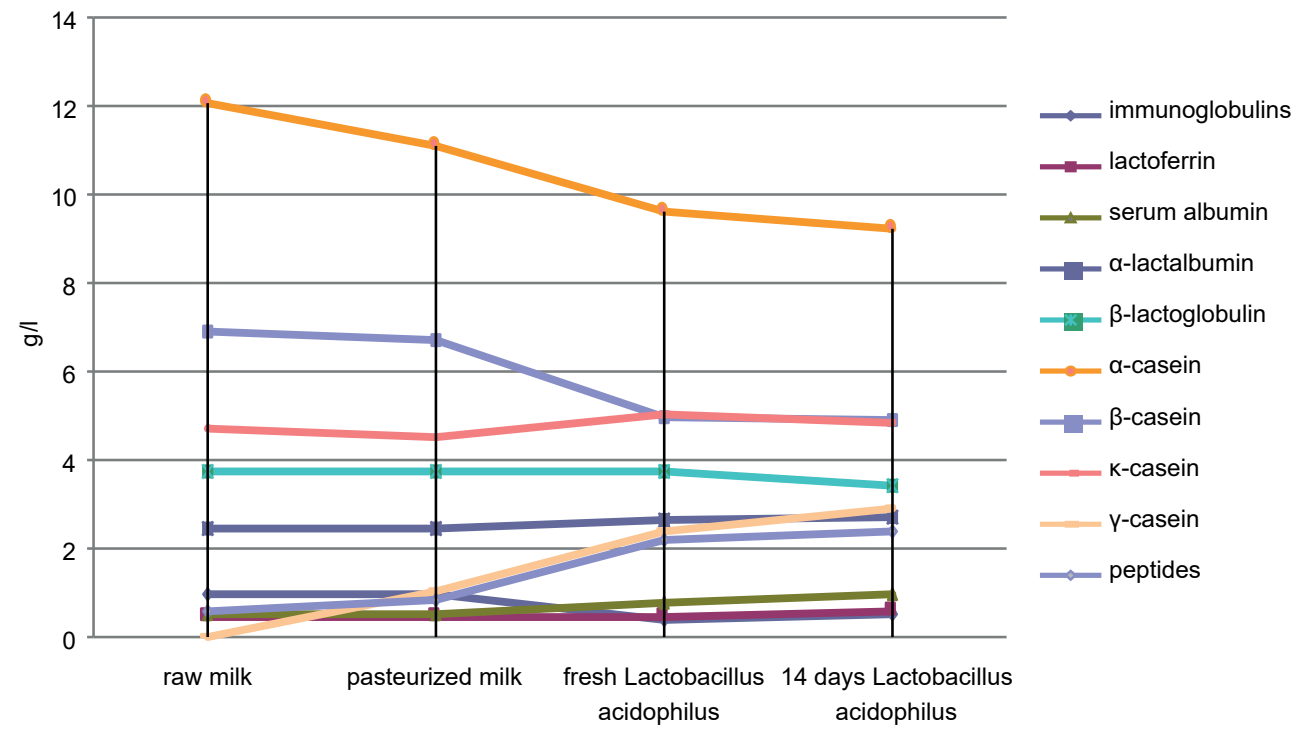

Fig. 5. Changes in protein fractions in milk and fermented with Lactobacillus acidophilus milk

Table 3. Changes of protein fractions fermented drinks stored for 14 days in comparison to pasteurised milk, $\%$

\begin{tabular}{|c|c|c|c|c|c|c|}
\hline Protein fractions & $\begin{array}{l}\text { Molecular } \\
\text { mass } \\
\mathrm{kDa}\end{array}$ & Yoghurt & Kefir & Acidified milk & $\begin{array}{l}\text { Bifidobacterium } \\
\text { milk }\end{array}$ & $\begin{array}{c}\text { Lactobacillus } \\
\text { acidophillus } \\
\text { milk }\end{array}$ \\
\hline Immunoglobulins & 150 & $57.0 \downarrow$ & $41.9 \downarrow$ & $25.8 \downarrow$ & $47.3 \downarrow$ & $46.2 \downarrow$ \\
\hline Lactoferrin & 80 & $25.0 \uparrow$ & $57.5 \uparrow$ & $72.5 \uparrow$ & 0 & $47.5 \uparrow$ \\
\hline Serum albumin & 66 & $160.0 \uparrow$ & $100.0 \uparrow$ & $174.0 \uparrow$ & $82.0 \uparrow$ & $84.0 \uparrow$ \\
\hline$\alpha$-casein & 26 & $19.3 \downarrow$ & $19.7 \downarrow$ & $13.0 \downarrow$ & $13.7 \downarrow$ & $17.0 \downarrow$ \\
\hline$\beta$-casein & 24 & $12.3 \downarrow$ & $30.3 \downarrow$ & $26.3 \downarrow$ & $23.5 \downarrow$ & $27.1 \downarrow$ \\
\hline$\kappa$-casein & 19 & $8.9 \downarrow$ & $3.8 \uparrow$ & $0.9 \uparrow$ & $13.6 \uparrow$ & $7.1 \uparrow$ \\
\hline$\beta$-lactoglobulin & 18 & $0.3 \downarrow$ & $13.5 \downarrow$ & $3.2 \downarrow$ & $19.1 \downarrow$ & $7.8 \downarrow$ \\
\hline$\alpha$-lactalbumin & 14 & $2.0 \downarrow$ & $26.1 \downarrow$ & $13.5 \uparrow$ & $4.9 \uparrow$ & $9.0 \uparrow$ \\
\hline Low molecular mass peptides & $<12$ & $159.2 \uparrow$ & $88.9 \uparrow$ & $360.5 \uparrow$ & $401.2 \uparrow$ & $193.8 \uparrow$ \\
\hline$\gamma$-casein & 6 & $114.9 \uparrow$ & $360.4 \uparrow$ & 0 & $18.8 \downarrow$ & $187.1 \uparrow$ \\
\hline
\end{tabular}

Arrows show increase or decrease of the proportion of each protein fraction.

drink dahi (similar to yoghurt) $\alpha s$-casein was hydrolysed more than $\beta$-casein, which is in accordance with the results obtained in this experiment.

Tzvetkova et al. (2007) described that proteolytic abilities of Lactobacillus milk rods are different in relation to $\alpha$-lactoalbumin and $\beta$-lactoglobulin, as $\alpha$-lactoalbumin is more easily hydrolysed. The abovedescribed phenomenon limits the abilities of those rods to decrease the allergenicity of $\beta$-lactoglobulin in fermented milks. Pescuma et al. (2008) reported 
that yoghurt starter bacteria hydrolyse up to $23 \%$ of $\alpha$-lactoalbumin and up to $18 \%$ of $\beta$-lactoglobulin. The results obtained in this survey refuted that thesis (Table 2 and Fig. 1). $\alpha$-lactoalbumin and $\beta$-lactoglobulin are, besides caseins, the most allergenic milk proteins. So kefir, with its low $\alpha$-lactoalbumin content and Bifidobacterium bifidum milk, with the lowest content of $\beta$-lactoglobulin (Table 2), were the most advantageous and least allergenic drinks among those examined.

Wróblewska et al. (2011) reported that the proteins most resistant to hydrolysis produced by lactic acid fermenting bacteria were serum albumin and lactoferrin, which stayed in fermented milks as the main allergens. In this study, the changes in the content of both of the above-mentioned protein were not large when compared to raw milk, and in acidified milk they were present in the largest amounts.

\section{CONCLUSIONS}

In pasteurised milk, the contents of $\alpha s$-, $\beta$ - and $\kappa$-casein were lower, whereas the $\gamma$-casein and peptide levels were higher in comparison to raw milk.

In all fermented milks, the changes in proteins and peptides relative to raw milk continued during storage: the levels of immunoglobulins, $\alpha s$ - and $\beta$-casein decreased whereas $\gamma$-casein and peptide content increased.

In fermented milks, an increase in protein fractions with a molecular mass similar to lactoferrin and serum albumin was observed relative to raw milk (with exception of Bifidobacterium milk), which could be caused by the aggregation of proteins and/or polypeptides.

Observed differences between fermented milks in the content of different proteins, including during chilled storage, demonstrates the different proteolytic abilities of starter cultures used in the production of fermented milks.

\section{REFERENCES}

Alhaj, O. A., Kanekanian, A. D., Peters, A. C. (2007). Investigation on whey proteins profile of commercially available milk-based probiotics health drinks using fast protein liquid chromatography (FPLC). Brit. Food J., 109, 6, 469-480.

AOAC (1990). Official methods of analysis. Arlington: A. Press.
Barłowska, J., Szwajkowska, M., Litwińczuk, Z., Król, J. (2011). Nutritional value and technological suitability of milk from various animal species used for dairy production. Compr. Rev. Food Sci. Food Safety, 10, 291-302.

Barłowska, J., Wolanciuk, A., Litwińczuk, Z., Król, J. (2012). Milk proteins' polymorphism in various species of animals associated with milk production utility. In W. L. Hurley (Ed.), Milk protein (pp. 235-264). InTech Open Science Open Minds.

Brodziak, A., Król, J., Litwińczuk, Z. (2015). Whey protein content and fatty acid profile in cow's milk used in intensive and conventional production systems with regard to stage of lactation. Turk. J. Vet. Anim. Sci., 39, 745-750.

Bertrand-Harb, C., Ivanowa, I. V., Dalgalarrondo, M., Haertllé, T. (2003). Evolution of $\beta$-lactoglobulin and $\alpha$-lactalbumin content during yoghurt fermentation. Int. Dairy J., 13, 1, 39-45.

Caira, S., Pizzano, R., Picariello, G., Pinto, G., Cuollo, M., Chianese, L., Addeo, F. (2012). Allergenicity of milk proteins. In W. L. Hurley (Ed.), Milk protein (pp. 173214). InTech Open Science Open.

Creamer, L. K. (2003). Casein nomenclature, structure and association properties. In H. Roginski, J. W. Fuquay, P. F. Fox (Eds.), Encyclopedia of dairy science (pp. 1895-1902). London: Academic Press.

Crudden, A., Afoufa-Bastien, D., Fox, P. F., Brisson, G., Kelly, A. (2005). Effect of hydrolysis of casein by plasmin on the heat stability of milk. Int. Dairy J., 15, 1017-1025.

Ismail, B., Nielsen, S. S. (2010). Invited review: Plasmin protease in milk: Current knowledge and relevance to dairy industry. J. Dairy Sci., 93, 4999-5009.

Król, J., Brodziak, A., Litwinczuk, A. (2011). Podstawowy skład chemiczny i zawartość wybranych białek serwatkowych w mleku krów różnych ras i w serwatce podpuszczkowej. Żywn. Nauka Techn. Jakość, 3(76), 74-83.

Kuczyńska, B., Puppel, K., Gołębiewski, M., Kordyasz, M., Grodzki, H., Brzozowski, P. (2012a). Comparison of fat and protein fractions of milk constituents in Montbeliarde and Polish Holstein-Fresian cows from one farm in Poland. Acta Vet. Brno, 81, 139-144.

Kuczyńska, B., Puppel, K., Gołębiewski, M., Metera, E., Sakowski, T., Słoniewski, K. (2012b). Differences in whey protein content between cow's milk collected in late pasture and early indoor feeding season from conventional and organic farms in Poland. J. Sci. Food Agric., 92, 2899-2904.

Laemmli, U. K. (1970). Cleavage of structural proteins during the assembly of the head bacteriophage T4. Nature, $227,680-685$. 
Liu, E., Zheng, H., Hao, P., Konna, T., Yu, Y., Kume, H., Oda, M., Ji, Z. (2012). A model of proteolysis and amino acid biosynthesis for Lactobacillus delbrueckii ssp. bulgaricus in whey. Curr. Microb., 65, 6. DOI: 10.1007/ s00284-012-0214-4

Lorenzen, P. Ch., Clawin-Radecher, I., Einhoff, K., Hammer, Ph., Hartmann, R., Hoffmann, W., ..., Devrese, M. (2011). A survey of the quality of extended shelf life (ESL) milk in relation to HTST and UHT milk. Int. J. Dairy Techn., 64, 2, 166-178.

Meisel, H. (1998). Overview on milk protein-derived peptides. Int. Dairy J., 8, 363-373.

Meisel, H. (1997). Biochemical properties of bioactive peptides derived from milk proteins: potential nutraceuticals for food and pharmaceutical applications. Livestock Prod. Sci., 50, 125-138.

Ng-Kwai-Hang, K. F. (2003). Milk proteins. Heterogeneity, fractionation and isolation. In H. Roginski, J. W. Fuquay, P. F. Fox (Eds.), Encyclopedia of dairy science (pp. 1881-1894). London: Academic Press.

Pescuma, M., Hebert, E. M., Bru, E., Font de Valdez, G., Mozzi, F. (2012). Diversity in growth and protein degradation by dairy relevant lactic acid bacteria species in reconstituted whey. J. Dairy Res., 79, 201-208.

Pescuma, M., Herbert, E. M. Mozzi, F., Font de Valdez, G. (2008). Whey fermentation by thermophilic lactic acid bacteria: Evolution of carbohydrates and protein content. Food Microbiol., 25(3), 442-451.

Pinto, G., Caira, S., Cuollo, M., Lilla, S., Chianese, L., Addeo, F. (2012). Bioactive casein phosphopeptides in dairy products as nutraceuticals functional foods. In W. L. Hurley (Ed.), Milk protein (pp. 3-44). InTech Open Science Open.
Reguła, A., Bonczar, G. (2005). Proteolytic activity of different starter cultures in ewe's milk. Milchwissenschaft, 60(3), 267-270.

Sfaxi, I. H., El-Ghaish, S., Ahmadova, A., Rabesona, H., Haertle, T., Chobert, J. M. (2012). Characterization of new strain Lactobacillus paracasei $\mathrm{I}-\mathrm{N}-10$ with proteolytic activity: Potential role in decrease in $\beta$-casein immune-reactivity. Eur. Food Res. Techn., 235, 3, $447-$ 455. DOI: $10.1007 / \mathrm{s} 00217-012-1772-1$

Szwajkowska, M., Wolanciuk, A., Barłowska, J., Król, J., Litwińczuk, Z. (2011). Bovine milk proteins as the source of bioactive peptides influencing the consumers' immune system - a review. Anim. Sci. Pap. Rep., 29, 4, 269-280.

Tzvetkova, I., Dalgalarrondo, M., Danova, S., Iliev, I., Ivanowa, I., Chobert, J. M., Haertle, T. (2007). Hydrolysis of major dairy proteins by lactic acid bacteria from Bulgarian yoghurts. J. Food Biochem., 31(5) 680-702.

Wróblewska, B., Kaliszewska, A. (2011). Immunoreactive and allergenic properties of fermented milk products present on the Polish market. Milchwissenschaft, 66(3), 300-303.

Yadav, H., Jain, S., Sinha, P. R., (2007). Evaluation of changes during storage of probiotic dahi at $7^{\circ} \mathrm{C}$. Int. J. Dairy Techn., 60(3), 205-210.

Yasser, H. H., Khemais, K., Max, J. P. (2010). Effect of plasmin, milk somatic cells and psychotrophic bacteria on casein fractions of ultra high temperature treated milk. Food Sci. Techn. Res., 16(1), 79-86.

Zúñiga, R. N., Tolkach, A., Kulozik, U., Aquilera, J. M. (2010). Kinetics of formation and physicochemical characterization of thermally-induced b-lactoglobulin aggregates. J. Food Sci., 75(5), E261-E268. 